\title{
Responses of soybean to water stress and supplemental irrigation in upper Indo-Gangetic plain: Field experiment and modeling approach
}

\author{
Prakash Kumar Jha ${ }^{\mathrm{a}}$, Soora Naresh Kumar ${ }^{\mathrm{b}}$, Amor V.M. Ines ${ }^{\mathrm{a}, \mathrm{c}, *}$ \\ ${ }^{a}$ Department of Plant, Soil, and Microbial Sciences, Michigan State University, MI 48824, USA \\ ${ }^{\mathrm{b}}$ Centre for Environment and Climate Resilient Agriculture, Indian Agricultural Research Institute (IARI), New Delhi 110012, India \\ ${ }^{\mathrm{c}}$ Department of Biosystems and Agricultural Engineering, Michigan State University, MI 48824, USA
}

\section{A R T I C L E I N F O}

\section{Keywords:}

Soybean

Water stress

Supplemental irrigation

Crop model

InfoCrop

\begin{abstract}
A B S T R A C T
Understanding better the impacts of extreme dry spell regimes is essential for optimizing water management under a changing and variable climate. Using field experiments and modeling studies, we examined the impacts of dry spells in soybean and identified better management of water resources under varying water-scarce conditions. Field experimental data from soybean (PUSA-2614) experiments (July-Oct 2014; IARI, New Delhi, India) were used to calibrate and validate InfoCrop-Soybean model. This model was used to simulate optimal timing of irrigation under different dry spell scenarios. Results showed that plants subjected to water stress during flowering and vegetative growth stages had significantly lower yields and total dry matter (TDM). Supplemental irrigation significantly increased TDM and yields. InfoCrop-Soybean could simulate plant responses to water stress, at various stages of crop growth, and to supplemental irrigation, with acceptable accuracy. The crop model was further used to simulate impacts of dry spells at different intensities and durations on soybean growth and yields by creating drought scenarios for the New Delhi region using 36 years of weather data (1978-2014). Simulations showed that a $20 \%$ reduction in rainfall during any fortnight (every 15th day) of the cropping season does not affect crop yield significantly. However, dry spells (50\% reduction in rainfall or more) in August and early September led to reduced yields, while supplemental irrigation during those dry spells could reduce yield losses. We envisage that the results of this study can help better manage water in soybean cultivation under dryland condition.
\end{abstract}

\section{Introduction}

Quantifying the effects of dry spells on soil moisture availability and crop performance is of paramount importance in dryland agriculture (Steduto et al., 2012; Jones, 2013; Osakabe et al., 2014; Moshelion et al., 2015; Pessarakli, 2014, 2016; Sadras et al., 2016). This is particularly pressing nowadays because of the expected water scarcity that could impact South Asia in the near future due to global environmental change (IPCC, 2014). Evidence suggests that monsoon-break-days are increasing, and the frequency of monsoon depressions is declining (IPCC, 2014). Rainfall deficit of more than $20 \%$ from climatological mean could lead to meteorological drought, whose impacts on soil moisture availability could lead to substantial agricultural drought. In India, rainfall received during the southwest monsoon season is critical for a successful agricultural season (Revadekar and Preethi, 2012; Prasanna, 2014).

Soybean [Glycine $\max$ (L.) Merr.], the third most widely grown crop in India (after rice and wheat), produces $10.5 \mathrm{Mt}(\sim 10.9$ Mha acreage) with a low productivity of $965 \mathrm{~kg} \mathrm{ha}^{-1}$ (FAOSTAT, 2014), and is mainly cultivated as a rainfed crop. Water stress is the most dominant factor causing the yield gap (Sentelhas et al., 2015). Water stress is particularly damaging during flowering, seed setting and seed filling. It reduces yield by lessening the number of pods, seeds and seed weight (Pedersen and Lauer, 2004), which is enhanced by a simultaneous temperature stress (Hatfield and Prueger, 2011; Wiebbecke et al., 2012). Depending on the variety, soybean-growing period ranges from 90 to 120 days and requires $450-700 \mathrm{~mm}$ of water during the growing season (Doorenbos and Kassam, 1979; Ludwig et al., 2011). Under different agro-climates, cultivars may be improved by cultivar selection and genetic improvement to better adapt to the varying environmental conditions (Sinclair et al., 2007, 2008, 2010, 2014; Gilbert et al., 2011; Li et al., 2013; Lehmann et al., 2013; Devi et al., 2014).

Evaluating new genetic resources in the field under different agroclimatic conditions however requires a lot of resources (time, labor, money), but can be aided by crop simulation models. Crop models have been used in the past for estimating potential production of crops (Van

\footnotetext{
* Corresponding author at: Department of Plant, Soil, and Microbial Sciences, 1066 Bogue St., Michigan State University, East Lansing, MI 48824, USA.

E-mail address: inesamor@msu.edu (A.V.M. Ines).
} 
Wart et al., 2013; Espe et al., 2016; Morell et al., 2016); in yield gap analysis, to determine and correct factors that can increase actual crop yield (Bhatia et al., 2006; van Ittersum et al., 2013; Grassini et al., 2013, 2015; Zhang et al., 2016), in decision support (Guillaume et al., 2016; Robert et al., 2016), on climate change impact and adaptation assessments (Aggarwal et al., 2009; Rosenzweig et al., 2014; Kumar et al., 2014; Kumar et al., 2016; Boote et al., 2016; Gummadi et al., 2016; Fan et al., 2017; Fodor et al., 2017; Martre et al., 2017; Lobell and Asseng, 2017), among others. Soybean growth and its responses to water stress had been simulated using crop models (Dietzel et al., 2016; Battisti et al., 2017; Giménez et al., 2017). Nielsen et al. (2002) used RZWQM and CROPGRO-Soybean models to estimate water stress and its impacts on soybean yield under a dryland condition.

In this study, we evaluate soybean responses to water stress under different agro-climatic scenarios in the Upper Indo-Gangetic Plain. Specifically, this study aims (i) to quantify the responses of soybean to water deficits through field experiments, (ii) to simulate soybean growth and yield in response to soil moisture deficits, and (iii) to simulate suitable water management strategies for optimizing yield under drought scenarios. We envisage that this study would help better understand the management of water for soybean cultivation in rainfed conditions.

\section{Materials and methods}

Three activities were conducted to meet the objectives of the study. First, a field experiment was conducted to quantify the performance of soybean under water stress conditions at different growth stages. Second, the experimental data was used to calibrate and verify the InfoCrop-soybean model. Third, the calibrated model was applied to simulate optimal timing of irrigation under different drought scenarios.

\subsection{Field experiment}

\subsubsection{Treatments}

To study water stress effects on soybean, field experiments were conducted during monsoon season of 2014 at IARI, New Delhi $\left(28^{\circ} 38^{\prime} \mathrm{N}, 77.10^{\prime} \mathrm{E}\right)$. A field experiment was conducted with a soybean variety DS 2614 during the monsoon season of 2014 with plot sizes of $6 \mathrm{~m} \times 4 \mathrm{~m}$. Pre-sowing seedbed was prepared by using a cultivator to till the soil (20-25 cm deep). Soybean seeds were sown on 14th July 2014 with a row spacing of $50 \mathrm{~cm}$ and plant spacing of $15 \mathrm{~cm}$, and depth of planting was at $5 \mathrm{~cm}$. An initial dose of nitrogen ( $20 \mathrm{~kg} / \mathrm{ha}$ ) was applied (urea; 45-0-0; $\mathrm{N}-\mathrm{P}_{2} \mathrm{O}_{5}-\mathrm{K}_{2} \mathrm{O}$ ) to the seedbeds as the soil in the field was low in nitrogen. We did not inoculate an initial rhizobium culture, but later nodules were observed in roots as they associated with soil bacterium (Rhizobium) population found at experimental field. Analysis of microbial population and their impact on soybean nitrogen uptake is beyond the purview of our study.

Five field experimental treatments were laid out on a homogenous field, three for water stress at vegetative stage, flowering stage and pod filling stage, and two treatments as fully rainfed and with supplemental irrigation (Table 1 ). To provide water stress, plots were covered with a rainout shelters $(6 \mathrm{~m} \times 4 \mathrm{~m})$ framed with polythene walls on the top and two sides to prevent rainfall water from entering. No irrigation was given to these plots during artificial stress periods (stress were provided by manual installation of shelters to the plots). To minimize the subsurface water flow and its effects, plots were surrounded by $0.5-\mathrm{m}$ channels, which helped draining the lateral flow from rainfall; sampling plants to measure physiological responses were performed at the central locations of the plots to minimize the impacts of lateral flow to crop response. Each treatment had four replications.

\subsubsection{Measurements}

Weather parameters (rainfall, minimum and maximum temperature, solar radiation) were recorded and collected at the IARI
Table 1

Period of stress given within a particular treatment.

\begin{tabular}{lll}
\hline Treatment & Condition & Period of stress (DAS) \\
\hline $\mathrm{T}_{1}$ (RF-VS-RF) & Rainfed & Up to 18 \\
& Stress during Vegetative stage & $\begin{array}{l}19-53 \text { (shelter } \\
\text { application) }\end{array}$ \\
& Rainfed & $54-101$ \\
& actual rainfall \\
$\mathrm{T}_{2}(\mathrm{RF}+\mathrm{BS})$ & Rainfed $^{\mathrm{a}}$ & distribution \\
& & Up to 53 \\
$\mathrm{~T}_{3}(\mathrm{RF}-\mathrm{FS}-\mathrm{RF})$ & Rainfed & $54-79$ (shelter \\
& Stress during Flowering stage & application) \\
& & $80-103$ \\
& Rainfed & Up to 79 \\
$\mathrm{T}_{4}$ (RF-PFS) & Rainfed & $80-105$ (shelter \\
& Stress during Pod Filling stage & application) \\
& & No stress \\
$\mathrm{T}_{5}$ (SI) & Supplemental Irrigation on 45 and & \\
& 86 DAS &
\end{tabular}

Note: DAS- Days after sowing, RF- Rainfed, VS- Stress during vegetative stage, RF + BSRainfed with biotic stress, FS- Stress during flowering stage, PFS-Stress during pod filling stage, SI-Supplemental Irrigation.

a These rainfed plots are heavily infested by soybean aphids and hence tagged as $\mathrm{RF}+\mathrm{BS}$; two applications of Mustang insecticide ( $200 \mathrm{~g} / \mathrm{ha}$ ) were applied to control aphids infestation (48 DAS and 64 DAS).

meteorological observatory, New Delhi.

For soil measurements, soil samples were air-dried, sieved through a $2 \mathrm{~mm}$ screen, mixed and used to determine various physico-chemical properties following soil science standard procedures (soil organic carbon (\%) by Walkley and Black, 1934; field capacity and wilting points (\% w/w) by Richards, 1947; soil available K (kg/ha) by Hanway and Heidel, 1952; soil available P (kg/ha) by Olsen et al., 1954; soil available $\mathrm{N}(\mathrm{kg} / \mathrm{ha})$ by Subbiah and Asija, 1956; soil texture by Bouyoucos, 1962; bulk density by Blake, 1965 and pH and EC (dS/m) by Jackson, 1973). The soil in the experimental site is slightly alkaline with low electrical conductivity and is well drained. The Yamuna alluvial soil of the experimental site is typical Haplustept with a $\mathrm{pH}$ of 8.16 and sandy loam in texture (sand, clay and silt percentages of $61 \%$, $20 \%$ and $19 \%$, respectively). The soil field capacity is $17.26 \%$ by volume while the permanent wilting point is $7.85 \%$. Soil is medium in organic carbon content and low in available nitrogen, medium in available potassium and available phosphorous.

Daily soil moisture was monitored using a FieldScout TDR 300 soil moisture meter. Daily soil moisture in terms of available water volume (\%) at a depth of $0-20 \mathrm{~cm}$ soil was recorded from five random places, in every plot, for each treatment. Thus, a total of 20 recordings were made from each treatment. Mean of all readings was considered representative soil moisture of that treatment. Observations of crop canopy and physiological parameters, such as leaf area index (LAI), gas exchange parameters, dry matter production and partitioning were taken on a weekly interval. Observations of yields and yield components were recorded at the time of harvest. Five plants were selected randomly in each plot at an interval of 5-7 days as "sample plants" for measuring crop parameters. Gas exchange parameters were recorded using a portable photosynthesis system - IRGA (LI-6400XT, LI-COR, USA) at 7 days interval during the cropping season. Observations were taken from 9:00 AM to 11:00 AM on physiologically mature leaves (generally top 4th-5th leaf). Leaf area index was recorded using plant canopy analyzer (LAI-2000; LI-COR, USA) at 5 days interval. Five plants were uprooted from each plot at 7 days interval for estimating dry matter production. The recoverable roots were washed and cleaned, and leaves and roots were separated from the stem. After that, they were kept in a pre-heated oven at $95^{\circ} \mathrm{C}$ for $48 \mathrm{~h}$, and weighed. During the growing season, sampling was done 11 times from each treatment.

\subsubsection{Statistical analysis}

The experimental data were tabulated and statistically analyzed 


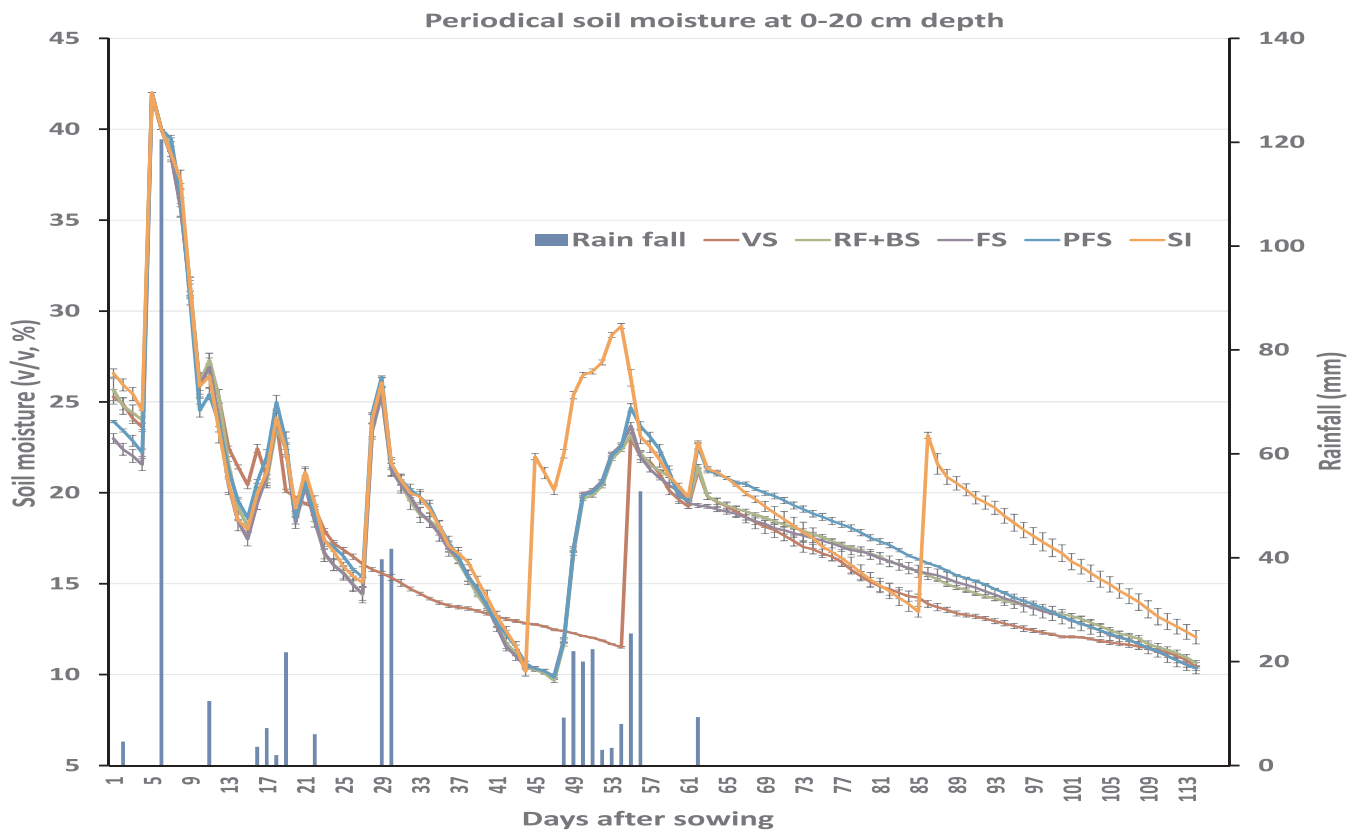

Fig. 1. Soil moisture content (\%, v/v) in the experimental plots under different stresses at $0-20 \mathrm{~cm}$ depth.

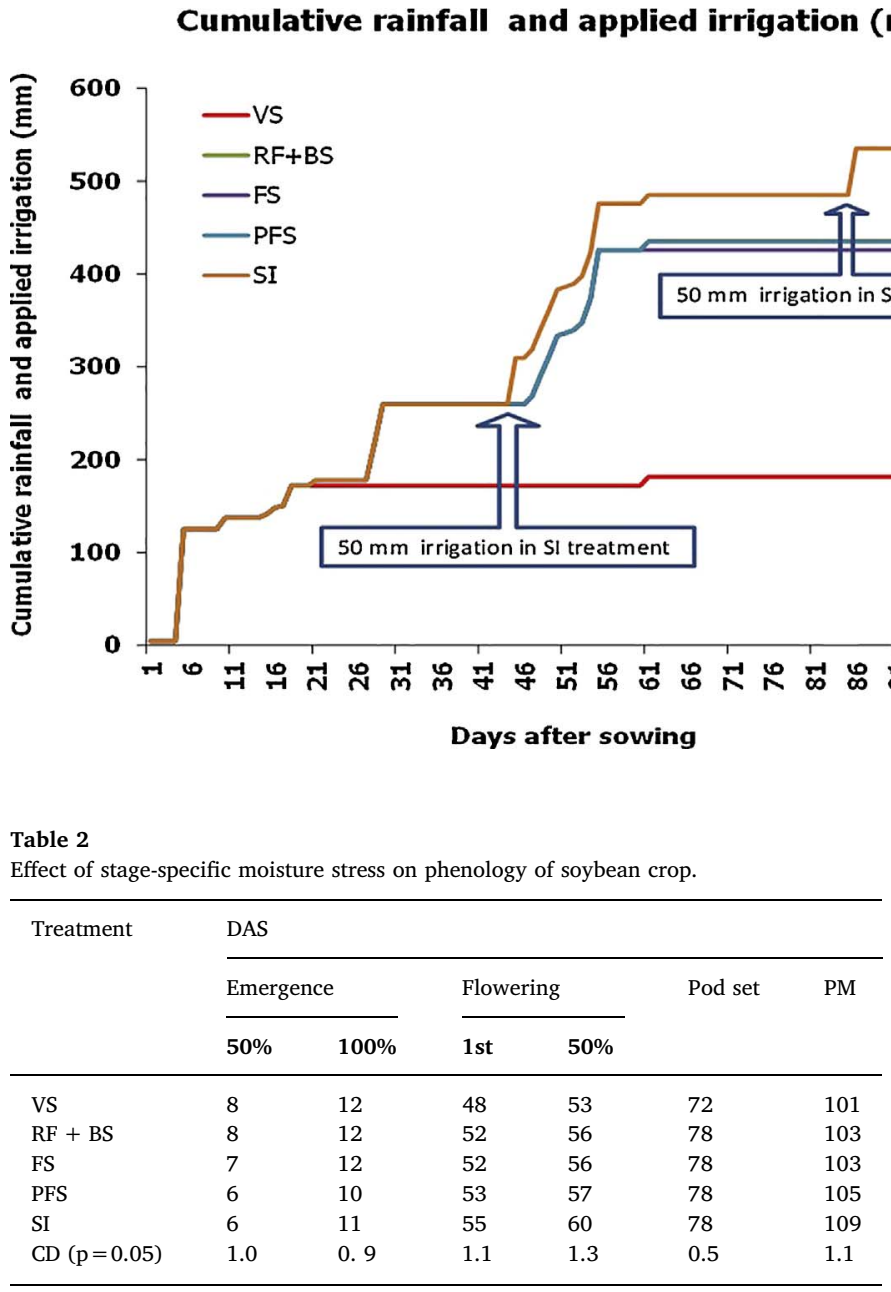

Note: DAS- Days after sowing; RF- Rainfed, VS- Stress during vegetative stage, RF + BSRainfed with biotic stress, FS- Stress during flowering stage, PFS-Stress during pod filling stage, SI-Supplemental irrigation; PM- Physiological Maturity.
Fig. 2. Cumulative rainfall and applied irrigation in the experimental plot of soybean in monsoon season of 2014. (Note: Cumulative rainfall and irrigation across the treatments overlaps before stress periods, see Table 1 for artificial period of stress).
(Randomized Block Design; Panse and Sukhatme, 1967) using a General Linear Model for univariate ANOVA, in SPSS (version 10). The critical difference (C.D.) was calculated at $5 \%$ level of significance for comparing the means.

\subsection{InfoCrop-soybean: calibration, validation and evaluation}

InfoCrop is a generic crop model that integrates soil nutrient dynamics and climate impact in addition to accounting for growth and yield loss due to pests and diseases, which is prevalent in tropical conditions (Aggarwal et al., 2006a,b) Its basic framework is based on MACROS (Penning de Vries et al., 1989), WTGROWS (Aggarwal et al., 1994), and ORYZA1 (Kropff et al., 1994) and SUCROS (van Laar et al., 1997) models. A windows user-friendly model written in Fortran Simulator Translator (FST) requires basic inputs e.g., crop, soil, weather and other management information, used for application of crop models in natural resource management and global change impact assessment. InfoCrop V2.0 was calibrated using the data collected under supplemental irrigation condition. Several iterations were done to 
Table 3

Leaf area index of soybean crop during different growth stages.

\begin{tabular}{lllll}
\hline Treatment & \multicolumn{4}{l}{ Leaf Area Index (LAI) } \\
\cline { 2 - 5 } & $\begin{array}{l}\text { Vegetative (40 } \\
\text { DAS) }\end{array}$ & $\begin{array}{l}\text { Mid-flowering } \\
\text { (65 DAS) }\end{array}$ & $\begin{array}{l}\text { LAI-Max } \\
\text { (75 DAS) }\end{array}$ & $\begin{array}{l}\text { Pod Filling } \\
\text { (90 DAS) }\end{array}$ \\
\hline VS & 1.88 & 2.77 & 3.64 & 3.10 \\
RF + BS & 1.27 & 2.06 & 3.03 & 2.55 \\
FS & 2.04 & 2.93 & 3.86 & 3.43 \\
PFS & 2.14 & 2.94 & 3.81 & 3.37 \\
SI & 2.07 & 3.05 & 3.91 & 3.55 \\
CD (p=0.05) & 0.244 & 0.292 & 0.239 & 0.223 \\
\hline
\end{tabular}

Note: DAS- Days after sowing; RF- Rainfed, VS- Stress during vegetative stage, RF + BSRainfed with biotic stress, FS- Stress during flowering stage, PFS-Stress during pod filling stage, SI-Supplemental Irrigation.

achieve parameter values that simulate better phenology, LAI, dry matter and yield. After a satisfactory performance was achieved, simulations were done for the other four treatments for validation. Simulation results of phenology, LAI, dry matter and yield were compared with those observed from the field. Model performance was evaluated using statistical indices e.g., Mean Bias Error (MBE) (Addiscott and Whitmore, 1987); Root Mean Square Error (RMSE) (Fox, 1981) and Agreement Index (AI) (Willmott, 1981).

\subsection{Simulating drought scenarios}

In this study, simulations of drought scenarios were done using 36 years of weather data from 1978 to 2014, New Delhi, India. The simulations were set up using the observed soil type, soybean variety and nutrient management used in the field experiments. To represent farmers' practices, the crop was grown as rainfed, and sowing in each year was done only when soil moisture had reached $85 \%$ of field capacity; this formed the baseline for our analysis. Then drought stress with varying intensity and duration were simulated. A total of 45 scenarios were generated, with 1620 scenario-year outputs. For quantitative analysis, yield deviation metric was calculated using:

Yield deviation $=\frac{\text { Yield }(\mathrm{s})-\text { Yield }(\mathrm{rf})}{\text { Yield }(\mathrm{rf})} * 100$

where, Yield(s) is mean of seed yield under stress condition, when rainfall is reduced from the normal, for 36 years, Yield(rf) is mean of seed yield under rainfed condition for 36 years.

Several iterative simulations were carried out to find the most suitable period for providing supplemental irrigation to minimize yield loss in the event of dry spell for 15 days in mid-season drought for sandy loam textured soil in the Delhi region.

\section{Results and discussion}

\subsection{Soil moisture}

The field experiment was aimed at quantifying the response of soybean to water deficits at different stages of growth. The crop received good rainfall during the early vegetative growth to early flowering period, and then no rainfall during the later pod filling stages and maturity period (Fig. 1).

Soil moisture of the $0-20 \mathrm{~cm}$ soil depth was monitored every day, and water deficit was provided using rainout shelters to the treatment plots. Volumetric soil moisture ranged from $10 \%$ to $42 \%$ in various treatments at different stages of crop growth (Fig. 1). Up to 25 DAS, soil moisture remained almost the same in all treatments. Thereafter, it was depleted for the vs treatment (see Table 1) from $24 \%$ on 17 DAS to $11 \%$ on 53 DAS. After withdrawing water stress (i.e., removing rainout shelter), soil moisture in this treatment had increased to $24 \%$ due to water available from rainfall and then gradually decreased again to $10 \%$ at the time of physiological maturity, as there were no rainfall events at the end of the growing season. In the rainfed plots, soil moisture varied from $10 \%$ to $42 \%$ depending on water availability from rainfall without imposing artificial water stress. In the third treatment (FS; Table 1), soil moisture depleted from $24 \%$ on 54 DAS to $16.5 \%$ on 79 DAS, the end of treatment period. Soil moisture in pod filling stress (PFS; Table 1) treatment depleted from $18 \%$ on 80 DAS to $10 \%$ at physiological maturity. These two treatments (FS and PFS) responded similarly, as there were no rainfall thereafter, so imposing artificial water stress did not make much difference. In supplemental irrigation (SI; Table 1) treatment, soil moisture increased from $11 \%$ to $22 \%$ on 45 DAS, and from $13 \%$ to $23 \%$ on 86 DAS due to irrigation. Cumulative water in SI treatment was more than the other treatments (Fig. 2).

\subsection{Soybean crop responses to water deficit treatments}

\subsubsection{Phenological observations}

The soybean seeds (DS-2614) took 6-8 days for 50\%, and 10-12 days for $100 \%$ germination (Table 2 ).

In SI treatment, flowering was delayed by 4-5 days as compared to the plants under rainfed condition. Moisture stress during vegetative stage hastened flowering by 7-8 days. Associated with earlier flowering, pod initiation was also early in the plants under vs treatment. Sufficient moisture availability under SI treatment after flowering had extended pod-filling stage and delayed physiological maturity (Korte et al., 1983).

\subsubsection{Plant growth and biomass}

The leaf area index (LAI) was consistently higher in supplemental irrigated condition, while the LAI was significantly lesser in rainfed plants (Table 3). The LAI did not differ significantly among FS, PFS and SI treatments at all growth stages. However, plants that were exposed to

Table 4

Plant biomass of soybean crop during different growth stages.

\begin{tabular}{|c|c|c|c|c|c|c|c|c|c|c|c|c|c|}
\hline \multirow[t]{3}{*}{ Treatment } & \multicolumn{13}{|c|}{ Partitioned dry weight of the plant at different growth stages (g plant ${ }^{-1}$ ) } \\
\hline & \multicolumn{4}{|c|}{ Vegetative } & \multicolumn{4}{|c|}{ Mid-flowering } & \multicolumn{5}{|c|}{ Physiological Maturity } \\
\hline & Root & Stem & Leaf & Total & Root & Stem & Leaf & Total & Root & Stem & Leaf & Pod weight & Total \\
\hline VS & 0.62 & 1.51 & 3.10 & 5.23 & 1.38 & 4.05 & 5.40 & 10.83 & 3.2 & 15.07 & 15.9 & 16.69 & 50.86 \\
\hline $\mathrm{RF}+\mathrm{BS}$ & 0.55 & 0.98 & 1.69 & 3.21 & 1.22 & 3.29 & 4.20 & 8.71 & 2.7 & 13.60 & 15.0 & 15.69 & 46.99 \\
\hline FS & 0.73 & 1.60 & 3.26 & 5.59 & 1.83 & 5.41 & 7.99 & 15.23 & 3.0 & 15.70 & 16.6 & 13.21 & 48.51 \\
\hline PFS & 0.81 & 2.97 & 3.94 & 7.72 & 1.66 & 6.03 & 8.07 & 15.76 & 3.1 & 13.99 & 15.2 & 23.74 & 56.03 \\
\hline SI & 1.06 & 3.45 & 5.50 & 10.01 & 2.19 & 5.41 & 7.22 & 14.82 & 3.5 & 18.57 & 20.3 & 28.84 & 71.21 \\
\hline $\mathrm{CD}$ at $\mathrm{p}=0.05$ & 0.22 & 0.74 & 0.93 & 1.18 & 0.26 & 1.29 & 2.1 & 3.21 & NS & 1.0 & 1.0 & 2.4 & 2.9 \\
\hline
\end{tabular}

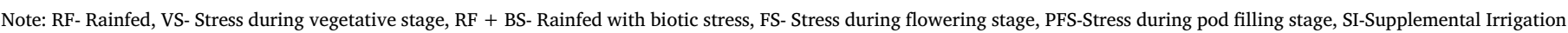


Table 5

Mean values of gas exchange parameters recorded through the crop season and canopy microclimate parameters of soybean under different moisture deficit treatments.

\begin{tabular}{|c|c|c|c|c|c|}
\hline \multirow[t]{2}{*}{ Parameter } & \multicolumn{5}{|l|}{ Treatment } \\
\hline & VS & $\mathrm{RF}+\mathrm{BS}$ & FS & PFS & SI \\
\hline $\mathrm{T}_{\mathrm{l}}-\mathrm{T}_{\mathrm{a}}\left({ }^{\circ} \mathrm{C}\right)$ & $-0.59 \pm 0.07$ & $-0.57 \pm 0.07$ & $-0.71 \pm 0.04$ & $-0.72 \pm 0.04$ & $-0.79 \pm 0.06$ \\
\hline Stomatal conductance $\left(\mathrm{mol} \mathrm{H}_{2} \mathrm{O} \mathrm{m}^{-2} \mathrm{~s}^{-1}\right)$ & $0.24 \pm 0.02$ & $0.26 \pm 0.03$ & $0.25 \pm 0.03$ & $0.28 \pm 0.03$ & $0.25 \pm 0.03$ \\
\hline Transpiration rate $\left(\mathrm{mmol} \mathrm{H}_{2} \mathrm{O} \mathrm{m}^{-2} \mathrm{~s}^{-1}\right)$ & $6.47 \pm 0.35$ & $6.61 \pm 0.42$ & $7.46 \pm 0.46$ & $7.46 \pm 0.47$ & $7.49 \pm 0.40$ \\
\hline Photosynthetic rate $\left(\mathrm{mol} \mathrm{CO}_{2} \mathrm{~m}^{-2} \mathrm{~s}^{-1}\right)$ & $17.19 \pm 0.77$ & $17.79 \pm 0.94$ & $19.86 \pm 0.79$ & $19.98 \pm 0.76$ & $19.61 \pm 0.86$ \\
\hline $\mathrm{Pn} / \mathrm{E}\left(\mu \mathrm{mol} \mathrm{CO} \mathrm{CO}_{2} \mathrm{mmol} \mathrm{H}_{2} \mathrm{O}\right)$ & $2.81 \pm 0.15$ & $2.89 \pm 0.17$ & $2.96 \pm 0.19$ & $2.85 \pm 0.18$ & $2.85 \pm 0.18$ \\
\hline Soil moisture (v/v\%) (Range) & $16.9(10.4-42)$ & $18.1(9.7-42)$ & $17.8(9.9-42)$ & $18.4(9.8-42)$ & $19.8(10.2-42)$ \\
\hline
\end{tabular}

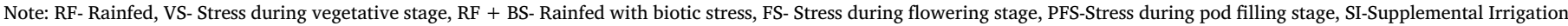

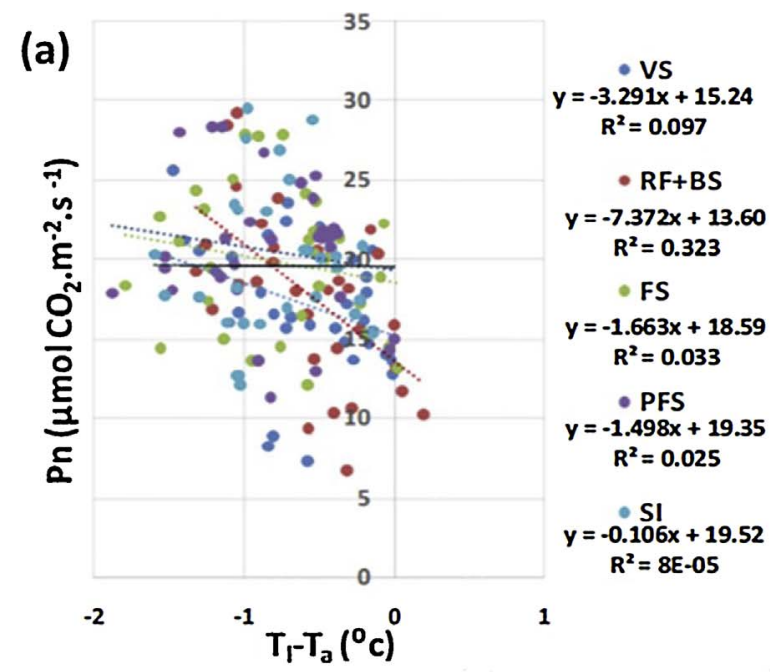

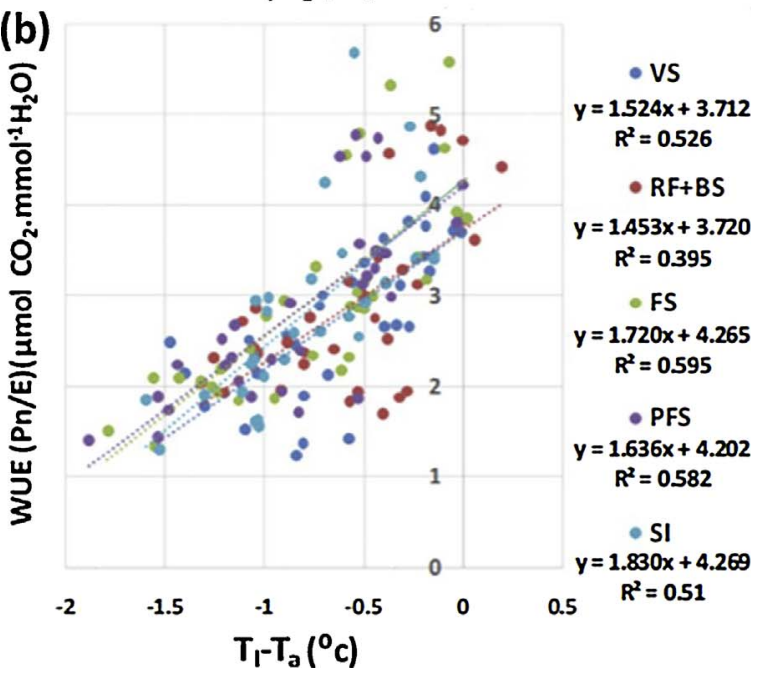

Fig. 3. Relationship of (a) net photosynthesis and (b) water use efficiency with $T_{1}-T_{a}$ across the treatments.

vegetative stage stress had significantly lower LAI than that of SI treatment, particularly at the post-flowering stage. Treatment 2 was kept completely rainfed earlier in the growing season but at the later vegetative and early flowering stages, the plants were infested with aphids, hence at the end of the experiment it was assigned as rainfed with biotic stress (RF + BS). Because of infestation by aphids, leaf area was significantly damaged and reduced and hence had lower LAI than VS.

The highest dry weight of recoverable roots, stem, leaves and total dry matter (TDM) were recorded in SI treatment, while least weight was recorded in RF + BS treatment followed by least pod weight, which led to the lower harvest index (Table 4). Plants under FS treatment had
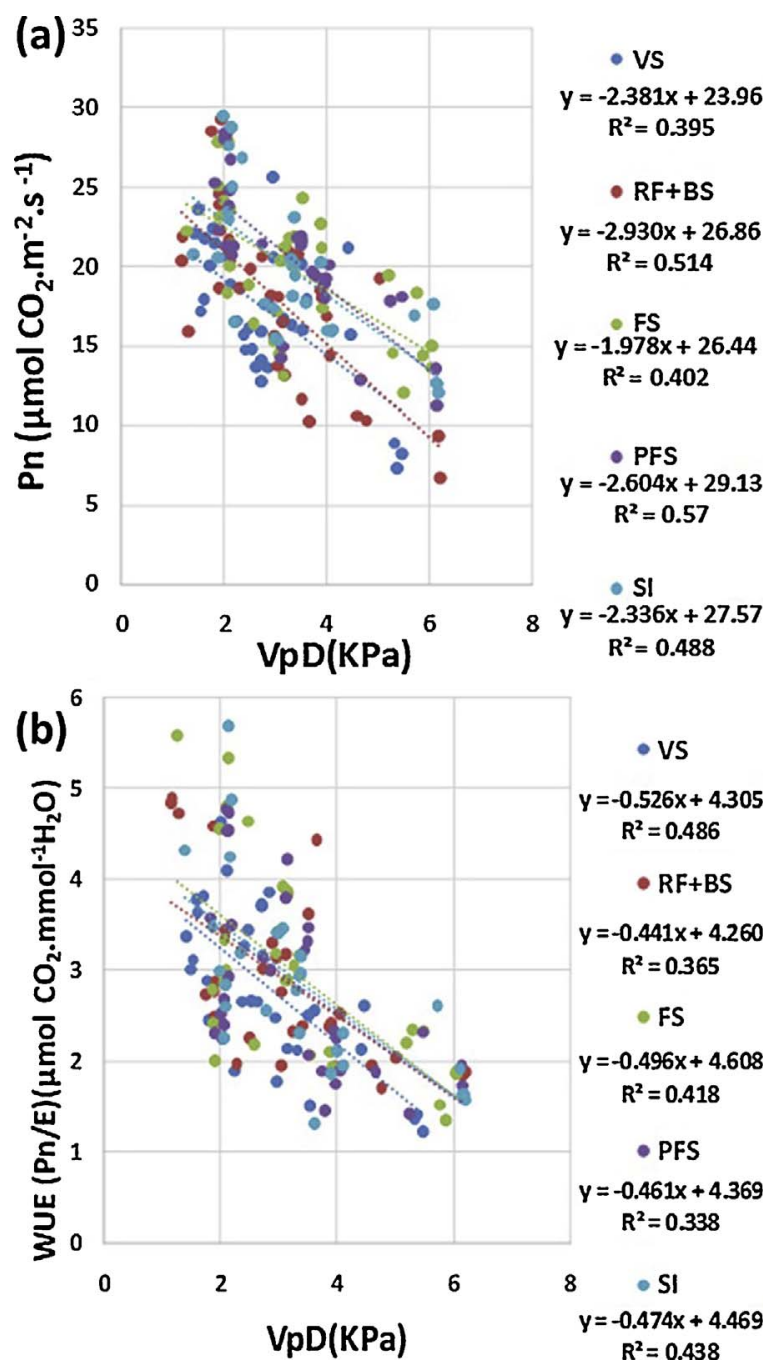

Fig. 4. Relationship of (a) net photosynthesis and (b) water use efficiency with VPD (air) across the treatments.

faster growth in leaf biomass after flowering to pod filling period as assimilates that remained in the leaves were translocated to stems instead to flowers and pods, it may be due to the significant flower abortion that occurred because of water stress during the flowering period (Eck et al., 1987). From flowering to physiological maturity, TDM accumulation had increased dramatically in plants under SI treatment. Plants that were exposed to stress at pod-filling stage had the second highest biomass dry weight (Table 4).

\subsubsection{Gas exchange parameters}

Gas exchange parameters were taken at 8 stages (7-days interval) of 


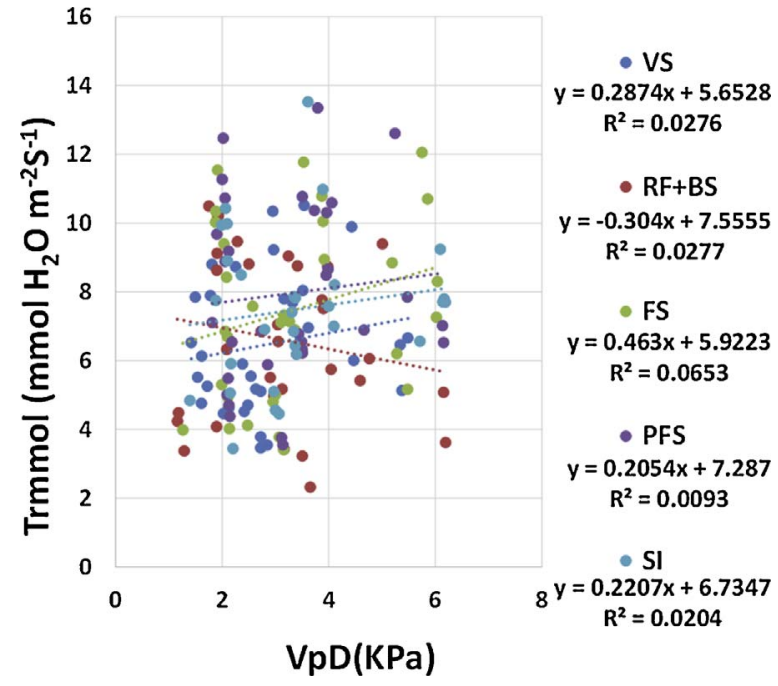

Fig. 5. Relationship of transpiration with VPD (air) across the treatments.

Table 6

Statistical indicators of InfoCrop-Soybean model performance (Calibration).

\begin{tabular}{llll}
\hline Parameters & MBE & RMSE & AI \\
\hline Days to 50\% germination & 1 & 1 & 0.47 \\
Days to 50\% flowering & -2 & 3 & 0.71 \\
Pod filling duration (days) & -1 & 1 & 0.80 \\
Days to 50\% physiological maturity & -2 & 3 & 0.75 \\
Stem weight $\left(\mathrm{kg} \mathrm{ha}^{-1}\right)$ & 480 & 561 & 0.71 \\
Leaf weight $\left(\mathrm{kg} \mathrm{ha}^{-1}\right)$ & 208 & 537 & 0.84 \\
Total dry matter $\left(\mathrm{kg} \mathrm{ha}^{-1}\right)$ & 933 & 1394 & 0.734 \\
Seed yield $\left(\mathrm{kg} \mathrm{ha}^{-1}\right)$ & 65 & 231 & 0.95 \\
\hline
\end{tabular}

Note: $\mathrm{MBE}=$ Mean bias error; $\mathrm{RMSE}=$ Root mean square error; $\mathrm{AI}=$ Agreement Index . crop growth. Observations were taken using IRGA (LI-6400 XT, LI-COR, USA) from 9:00 AM to 11:00 AM on physiologically mature leaves (generally top 4th -5 th leaf) at the rate of 20 readings per plot and their mean values for all these stages were taken to estimate the overall performance of the crop. Data indicated that the leaf of soybean crop was cooler than ambient air, which suggests active transpiration (Table 5). Plants under SI treatment had significantly cooler canopy than plants under water stressed condition or rainfed condition, which is in agreement with the findings of Jackson et al. (1981). Plants in RF and vs treatment had warmer canopy than in the other plots, but the temperatures were still lower than the ambient air temperatures of about $36{ }^{\circ} \mathrm{C}$. The mean conductance of stomata was highest in PFS and SI treatments while plants in vs and RF treatment had significantly lower stomatal conductance (Table 5). Consequently, transpiration rate and photosynthetic rate also followed a similar trend that of the difference of canopy and air temperature but the instantaneous water use efficiency $($ WUE $=$ Pn/E) did not differ significantly among the treatments.

The photosynthetic rate declined across all treatments except in SI, as difference in leaf temperature and air temperature decreased to zero (Fig. 3a). It means supplemental irrigation maintained suitable environment so that even after air temperature increased, stomatal conductance was higher (Table 5), which supports photosynthesis. Stomatal conductance affects both photosynthetic rate and transpiration (Zhou et al., 2014) Water use efficiency (WUE) increased as leaf temperature approached closer to air temperature (Fig. 3b), but our later discussion will illustrate that VPD is likely what is varying with Tl-Ta to create this WUE response to Tl-Ta.

The photosynthetic rate and instantaneous WUE (Pn/E) were negatively correlated with vapour pressure deficit (VPD) (Fig. 4a,b). Tomeo and Rosenthal (2017) have reported that water use efficiency and photosynthetic rate increases with stomatal conductance but it might increase with mesophyll conductance (i.e., CO2 diffusion rate from sub-stomatal region to actual sites of carboxylation), which is out of the scope of this study. WUE is the ratio of carbon assimilation after

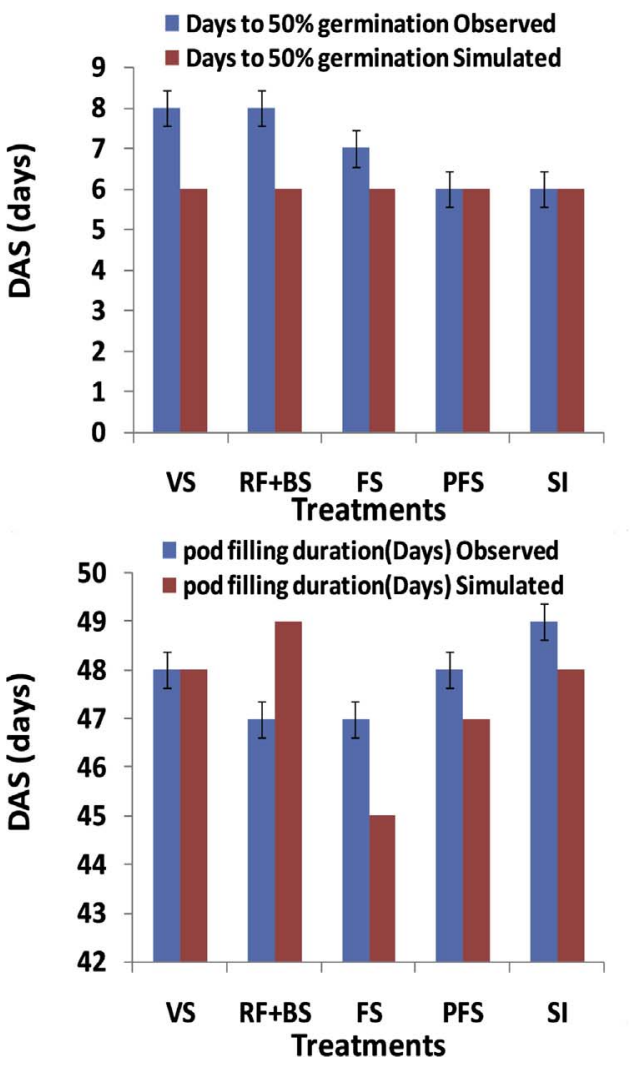

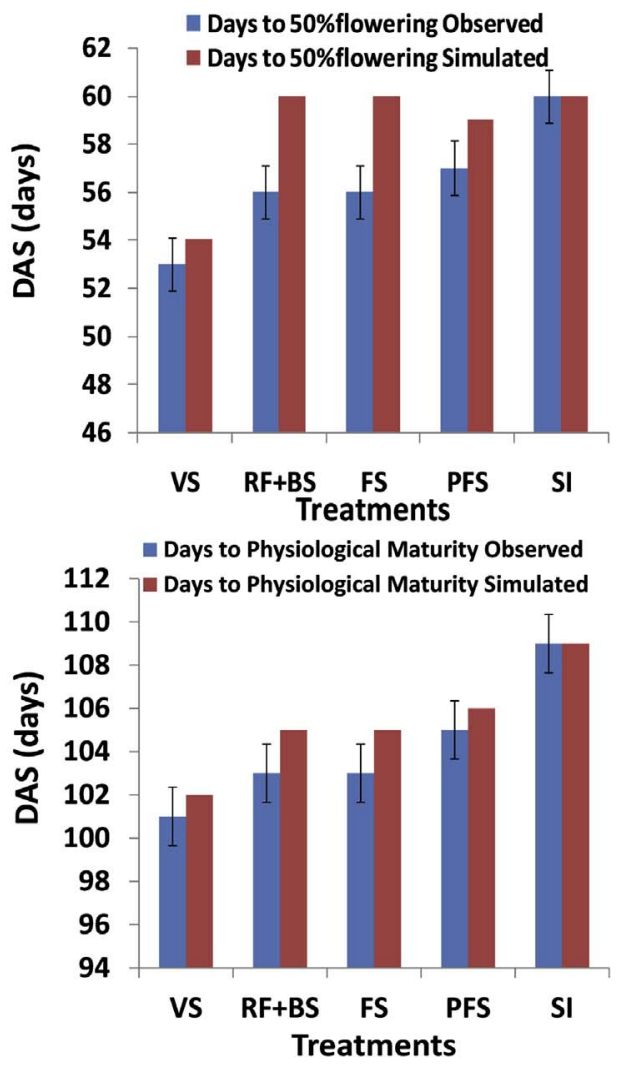

Fig. 6. Observed and simulated values of phenological events of soybean in different water deficit treatments. 

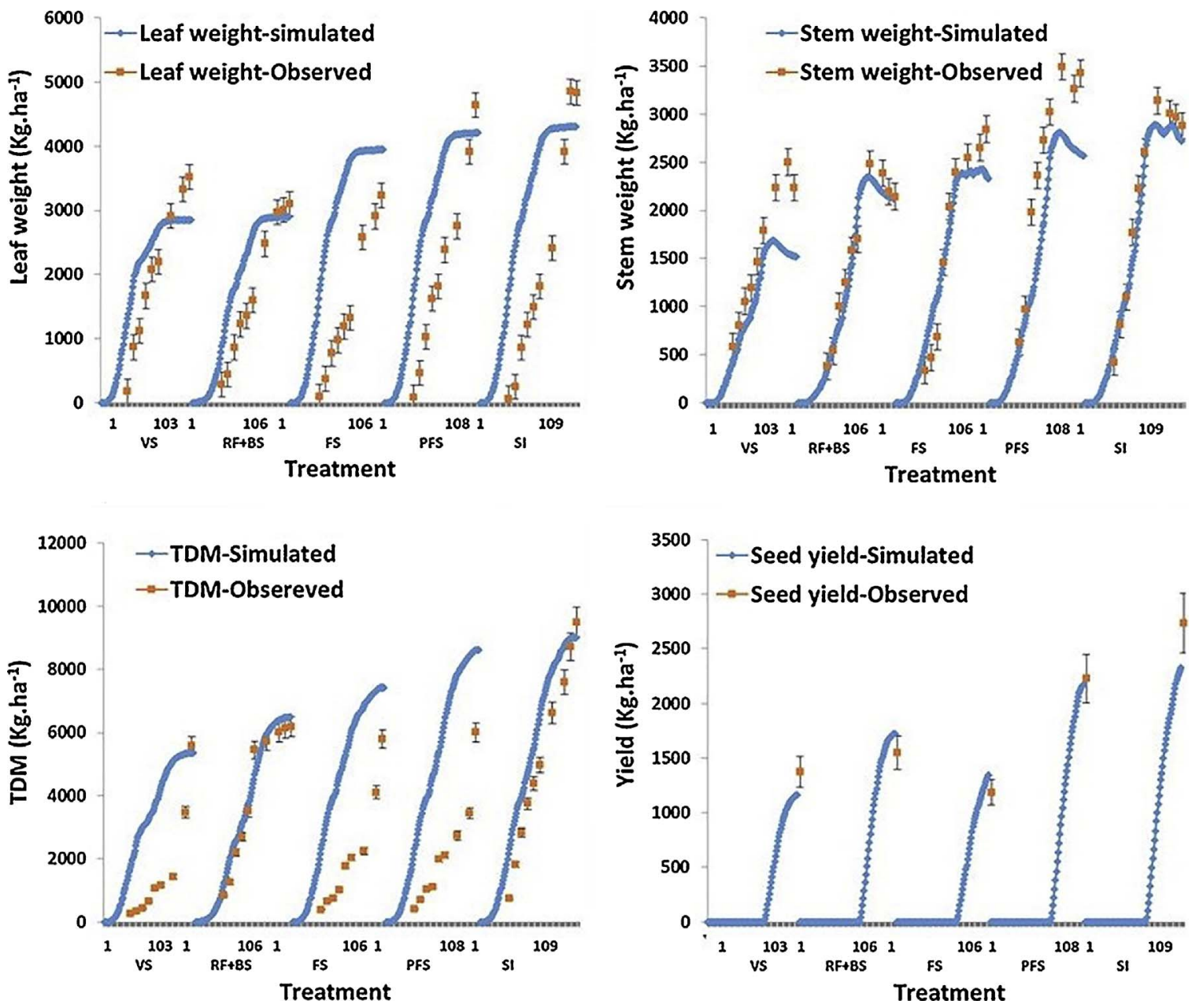

Fig. 7. Observed and simulated values of stem and leaf dry matter, TDM and yield of soybean at physiological maturity in different water deficit treatments

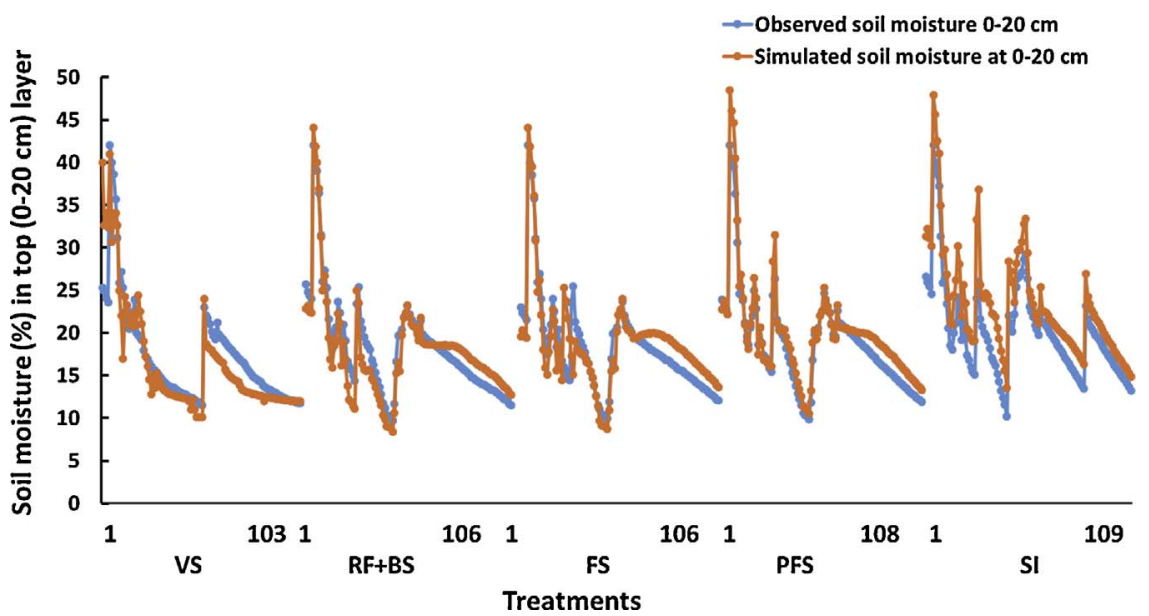

Fig. 8. Observed and simulated soil moisture across the treatments in soybean field.

photosynthesis over transpired water, which connects the link between carbon and water cycle in agroecosystems (Niu et al., 2011). Studies have shown that VPD is linearly correlated with transpiration in different soybean cultivars (Fletcher et al., 2007; Sinclair et al., 2008; Gilbert et al., 2011; Sinclair, 2017). We can visualize these correlations in Fig. 4(a,b). Stomatal conductance and net photosynthetic rates are more sensitive to increase in air VPD than increases in leaf temperature (Figs. 3a and Fig. 4a). The plot between transpiration and VPD showed no significant change in transpiration with-in a given range of VPD (Fig. 5). However, photosynthesis is affected significantly owing to stomatal limitation to $\mathrm{CO}_{2}$ under increasing VPD due to decreasing stomatal conductance (Zhang et al., 2017) apart from other non-stomatal regulation of photosynthesis. The negative slope for treatment $\mathrm{RF}+\mathrm{BS}$ might be due to biotic stress interference leading to erosion of leaf surface area and hence influence on gaseous exchange between atmosphere and leaf surface which is beyond the scope of this study.

\subsection{Simulation results of InfoCrop model}

The InfoCrop soybean model parameters and interpolation functions 

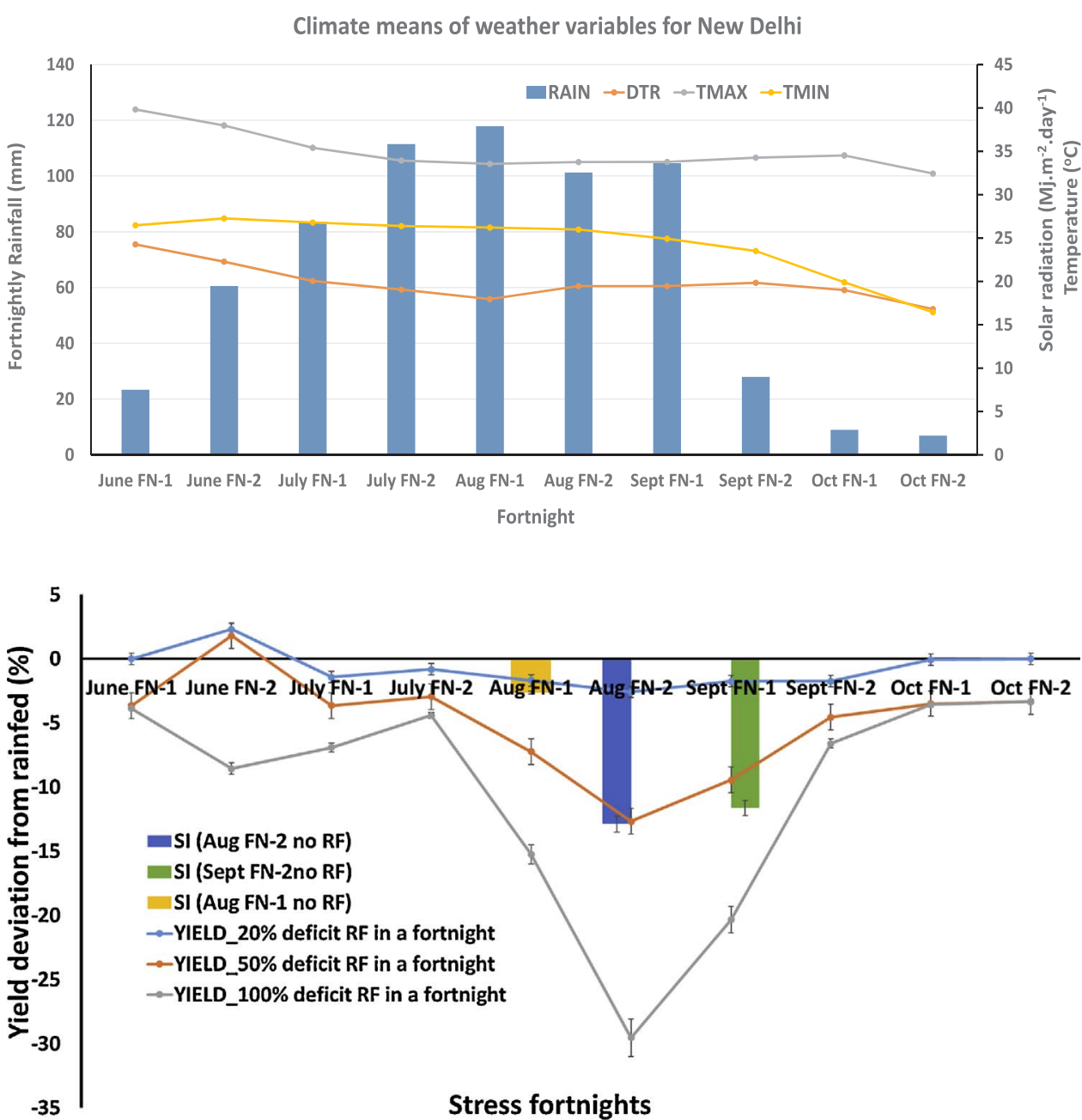

ig. 10. Percent deviation in yield of soybean (bar) and reduction in yield loss (line) under supplement irrigation in different drought scenario. Note: FN fortnight (15th day).
Fig. 9. Climate mean of fortnight weather variables over 30 years for New Delhi.

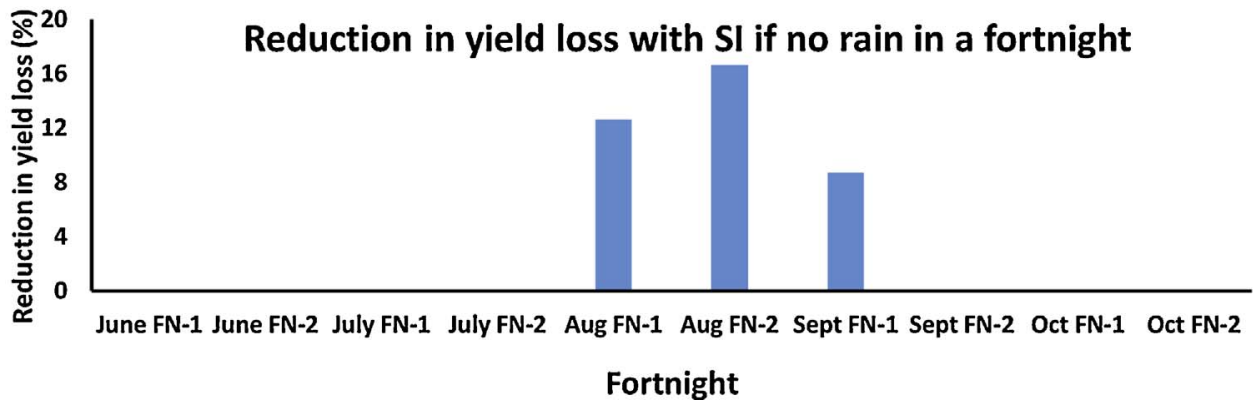



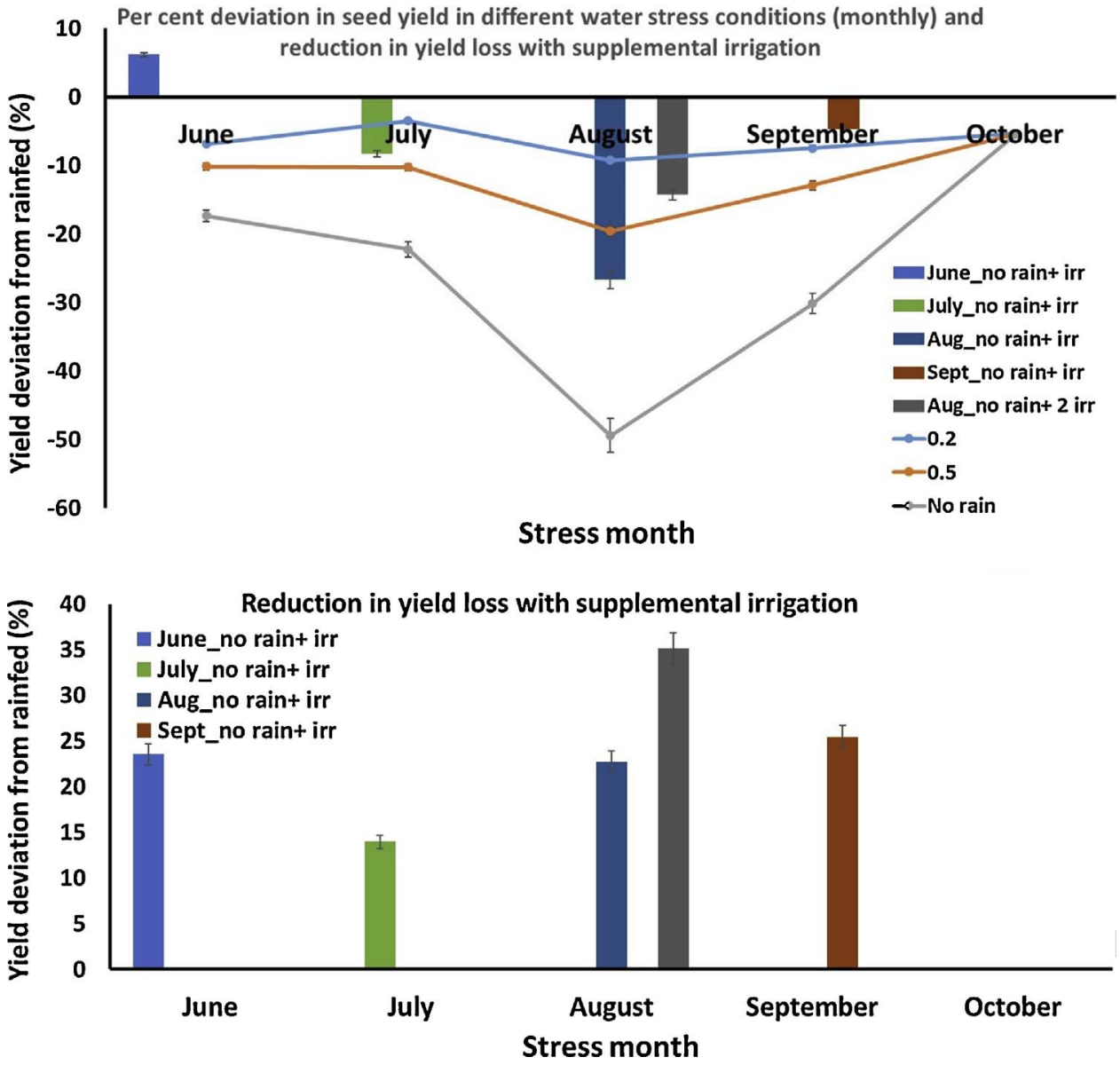

Fig. 11. Percent deviation in seed yield (bar) and reduction in yield loss (line) under supplemental irrigation in month dry spell scenario over 30 years in New Delhi.
We also evaluated the capability of InfoCrop-Soybean model to simulate soil moisture to ascertain its suitability to study optimal irrigation timing under drought scenarios in the future. Results showed that the model could simulate satisfactorily the variability and magnitude of soil moisture under the five field experimental treatments (calibration (SI) and validation runs (VS, RF + BS, FS, PFS), respectively) (Fig. 8).

\subsection{Simulation of suitable water management strategy for maximizing yield under drought scenarios}

The verified InfoCrop-Soybean model was used to simulate the impacts of dry spells of different intensity and duration on growth and yield of soybean. Furthermore, the model was used to study optimal timing of irrigation under different drought scenarios. Simulations were done for New Delhi region using 36 years weather data (1978-2014) using the soil type, soybean variety, cultural and nutrient management practices done in the field experimental setup.

The climatological mean of Delhi weather indicated that the maximum temperature (Tmax) during monsoon season ranged between 32.5 and $39^{\circ} \mathrm{C}$ while the minimum temperature (Tmin) varied between 16 and $26.5^{\circ} \mathrm{C}$ with slightly cooler temperatures towards crop maturity. Daily mean solar radiation (DTR) ranged between 16 and $25 \mathrm{MJ} \mathrm{m}^{-2}$ day $^{-1}$ (Fig. 9).

Seasonal mean rainfall (Rain) during June to October is $648 \mathrm{~mm}$ with highest rainfall of $118 \mathrm{~mm}$ during August first fortnight, followed by $110 \mathrm{~mm}$ in July 2nd fortnight and 101-104 mm rainfall in August 2nd fortnight and September 1st fortnight. Lesser rainfall is received in September 2nd fortnight and later.

Analysis of the 30 years of simulation data on soybean growth and development in Delhi indicated that rainfed soybean has mean yield of
$2000 \mathrm{kgha}^{-1}$. Simulation results indicated that in Delhi region, a $20 \%$ reduction in rainfall from climatological mean during any fortnight of crop season does not affect the crop yield significantly (Fig. 10). However, a 50\% reduction in rainfall from climatological mean during 1st fortnight of August, 2nd fortnight of August and 1st fortnight of September can cause $7.5 \%, 13 \%$ and $9.5 \%$ reduction in soybean grain yield, respectively (Fig. 10). If any of these fortnights experience dry spell (no rain) then the yield loss would be $15 \%, 30 \%$ and $20 \%$, respectively. Yield loss can be offset with one irrigation application during the 1st fortnight of August. Such intervention during dry spells in August (2nd fortnight) or in September (1st fortnight) can minimize the yield loss by $12-14 \%$.

When simulations were done with monthly dry spells, significant yield reductions were observed (Fig. 11). A 20\% reduction in rainfall from climatological mean during any month of crop season can reduce the grain yield up to $10 \%$ with more impact of dry spell during August. A $50 \%$ reduction in rainfall from climatological mean during June or July can cause $10 \%$ reduction in yield and no rainfall at all during June or July can cause $18-22 \%$ yield reduction (Fig. 11). Delay in sowing due to late onset of monsoon can cause such yield losses. Timely sowing (last week of June) with irrigation can provide higher yield than mean performance of crop in this region. Reduction in rainfall by $50 \%$ in August can cause $20 \%$ yield loss and in case of dry spell during this month, yield loss would be $50 \%$. Yield loss can be minimized to $25 \%$ with one irrigation application and to $14 \%$ with two irrigation applications during dry spell in this month (Fig. 11). During September, a $50 \%$ reduction in rainfall cause $14 \%$ yield loss while dry spell during this month will cause $30 \%$ yield loss. This $30 \%$ loss can be minimized to $5 \%$ loss with one supplemental irrigation during dry spell in September. Further, data indicate that if the rainfall in July (1st fortnight) is about $40 \mathrm{~mm}$ (50\% deviation from the normal monthly precipitation), then 
yield may reduce by around $4 \%$ as compared to the mean yield of $2000 \mathrm{~kg} \mathrm{ha}^{-1}$, if all other fortnights receive climatological mean rainfall (Fig. 9). Similarly, a rainfall of $55 \mathrm{~mm}$ in July 2nd fortnight (50\% deviation from the normal monthly precipitation) may cause a $4 \%$ reduction in yield. $60 \mathrm{~mm}$ rainfall in August 1st fortnight will reduce soybean yield by $7 \%$ while $50 \mathrm{~mm}$ of rainfall each during 2 nd fortnight of August and 1st fortnight of September can cause 11-13\% yield loss. Similarly, on monthly basis, a $95 \mathrm{~mm}$ rainfall during July can cause a yield reduction of $10 \%$ as compared to the mean yield of $2000 \mathrm{~kg} \mathrm{ha}^{-1}$, if all other months received climatological mean rainfall. Similarly, a $110 \mathrm{~mm}$ of rainfall during August can cause $20 \%$ yield loss while $60 \mathrm{~mm}$ rainfall during September can cause a yield reduction of $13 \%$, if all other months received climatological mean rainfall.

\section{Summary and conclusions}

Indian agriculture is predominantly monsoon dependent, and productivity of rainfed crops is highly unstable due to rainfall variability. In view of the projected increase in rainfall variability in future climates, the possibility of dry spells or droughts of varying intensity and duration coinciding with different stages of crop increases. A better understanding of the effect of dry spells and droughts of varying intensity and duration is essential for optimizing the timing of supplemental irrigation under water scarce situations to minimize yield losses. Among the monsoon (kharif) season crops, pulse and oilseed crops are grown rainfed in marginal lands or with fewer inputs. Soybean is mainly grown on rainfed condition subjected to dry spell often in India. Thus, the present study was carried out with the specific objectives to study and simulate the responses of soybean to water deficit and to simulate suitable water management strategy for maximizing yield under drought scenarios. The results of this study can be summarized as follows:

- water stress during vegetative growth and flowering affected soybean yield significantly;

- InfoCrop-Soybean could simulate the plant response to water stress at various stages of growth with acceptable levels of MBE, RMSE and AI, but further calibration is needed to strengthen model response to the soil water stress;

- water stress during August and early September can significantly reduce soybean yield in Delhi region, and supplemental irrigation in August, in the event of a dry spell, can minimize yield loss.

On a final note, as the model was developed for Indian conditions, when applying the InfoCrop-Soybean model to other geographic locations for understanding soybean responses to drought scenarios, one may consider improving or adding modules to the model, e.g., groundwater interactions, salinity, pest and diseases, among others.

\section{Acknowledgements}

The authors acknowledge the funding support from National Innovations in Climate Resilient Agriculture (NICRA) project by Indian Council of Agricultural Research (ICAR), New Delhi, India and staff support from Indian Agricultural Research Institute (IARI), New Delhi, India. We thank the editors and reviewers for their comments and suggestions to improving the quality of the paper.

\section{References}

Addiscott, T.M., Whitmore, A.P., 1987. Computer-simulation of changes in soil minera nitrogen and crop nitrogen during autumn, winter and spring. J. Agric. Sci. 109, 141-157.

Aggarwal, P.K., Kalra, N., Singh, A.K., Sinha, S.K., 1994. Analyzing the limitations set by climatic factors, genotype, water and nitrogen availability on productivity of wheat I. The model description, parametrization and validation. Field Crops Res. 38 (2), 73-91.
Aggarwal, P.K., Kalra, N., Chander, S., Pathak, H., 2006a. Info crop: a dynamic simulation model for the assessment of crop yields, losses due to pests: and environmental impact of agroecosystems in tropical environments. I. Model description. Agric. Syst. 89, $1-25$.

Aggarwal, P.K., Banerjee, B., Daryaei, M.G., Bhatia, A., Bala, A., Rani, S., Chander, S., Pathak, H., Kalra, N., 2006b. InfoCrop: a dynamic simulation model for the assessment of crop yields, losses due to pests: and environmental impact of agro-ecosystems in tropical environments. II. Performance of the model. Agric. Syst. 89, 47-67.

Aggarwal, P.K., Kumar, S.N., Bhatia, V.K., Bhoomiraj, K., 2009. Impacts of global climate change on oil seed crops. Vegetable Oil Scenario: Approaches to Meet Global Demand. pp. 247-255.

Battisti, R., Sentelhas, P.C., Boote, K.J., Câmara, G.M.D.S., Farias, J.R., Basso, C.J., 2017 Assessment of soybean yield with altered water-related genetic improvement traits under climate change in Southern Brazil. Eur. J. Agron. 83, 1-14.

Bhatia, V.S., Singh, P., Wani, A.V., Rao, R.K., Srinivas, K., 2006. Yield Gap Analysis of Soybean, Groundnut, Pigeonpea and Chickpea in India Using Simulation Modeling. International Crops Research Institute for the Semi-Arid Tropics (ICRISAT), Andhra Pradesh, India.

Blake, G.R., 1965. Bulk density. Methods of Soil Analysis. American Society of Agronomy, Madison, WI, pp. 374-390.

Boote, K.J., Jones, J.W., Tollenaar, M., Dzotsi, K.A., Prasad, P.V., Lizaso, J.I., 2016. Testing approaches and components in physiologically based crop models for sensitivity to climatic factors. In: In: Hatfield, J.L., Fleisher, D.H. (Eds.), Advances in Agricultural Systems Modeling-Improving Modeling Tools to Assess Climate Change Effects on Crop Response, vol. 7. American Society of Agronomy, Crop Science Society of America, and Soil Science Society of America, pp. 1-32.

Bouyoucos, G.J., 1962. Hydrometer method improved for making particle size analysis of soils. Agron. J. 54, 464-465.

Devi, J.M., Sinclair, T.R., Chen, P., Carter, T.E., 2014. Evaluation of elite southern maturity soybean breeding lines for drought-tolerant traits. Agron. J. 106 (6), 1947-1954.

Dietzel, R., Liebman, M., Ewing, R., Helmers, M., Horton, R., Jarchow, M., Archontoulis, S., 2016. How efficiently do corn-and soybean-based cropping systems use water? A systems modeling analysis. Global Change Biol. 22 (2), 666-681.

Doorenbos, J., Kassam, A.H., 1979. Yield Response to Water FAO Irrigation and Drainage Paper No. 33. FAO, Rome.

Eck, H.V., Mathers, A.C., Musick, J.T., 1987. Plant water stress at various growth stages and growth and yield of soybeans. Field Crops Res. 17 (1), 1-16.

Espe, M.B., Cassman, K.G., Yang, H., Guilpart, N., Grassini, P., Van Wart, J., Anders, M., Beighley, D., Harrell, D., Linscombe, S., McKenzie, K., 2016. Yield gap analysis of US rice production systems shows opportunities for improvement. Field Crops Res. 196, 276-283.

FAO, 2014. FAOSTAT database collections. Food and Agriculture Organization of the United Nations. Rome. Access date: 2015-04-22. URL: http://www.fao.org/faostat/ en/\#data/QC.

Fan, D., Ding, Q., Tian, Z., Sun, L., Fischer, G., 2017. A cross-scale model coupling approach to simulate the risk-reduction effect of natural adaptation on soybean production under climate change. Hum. Ecol. Risk Assess. 23 (3), 426-440.

Fletcher, A.L., Sinclair, T.R., Allen, L.H., 2007. Transpiration responses to vapor pressure deficit in well-watered 'slow-wilting 'and commercial soybean. Environ. Exp. Bot. 61 (2), 145-151.

Fodor, N., Challinor, A., Droutsas, I., Ramirez-Villegas, J., Zabel, F., Koehler, A.K., Foyer, C.H., 2017. Integrating plant science and crop modelling: assessment of the impact of climate change on soybean and maize production. Plant Cell Physiol. 58 (11), 1833-1847.

Fox, D.G., 1981. Judging air quality model performance. Bull. Am. Meteorol. Soc. 62, 599-609.

Gilbert, M.E., Holbrook, N.M., Zwieniecki, M.A., Sadok, W., Sinclair, T.R., 2011. Field confirmation of genetic variation in soybean transpiration response to vapor pressure deficit and photosynthetic compensation. Field Crops Res. 124 (1), 85-92.

Giménez, L., Paredes, P., Pereira, L.S., 2017. Water use and yield of soybean under various irrigation regimes and severe water stress: application of AquaCrop and SIMDualKc models. Water 9 (6), 393.

Grassini, P., Eskridge, K.M., Cassman, K.G., 2013. Distinguishing between yield advances and yield plateaus in historical crop production trends. Nat. Commun. 4, 2918.

Grassini, P., van Bussel, L.G., Van Wart, J., Wolf, J., Claessens, L., Yang, H., Boogaard, H., de Groot, H., van Ittersum, M.K., Cassman, K.G., 2015. How good is good enough? Data requirements for reliable crop yield simulations and yield-gap analysis. Field Crops Res. 177, 49-63.

Guillaume, S., Bruzeau, C., Justes, E., Lacroix, B., Bergez, J.E., 2016. A conceptual model of farmers' decision-making process for nitrogen fertilization and irrigation of durum wheat. Eur. J. Agron. 73, 133-143.

Gummadi, S., Wheeler, T., Osborne, T., Turner, A., 2016. Addressing the uncertainties associated in assessing the impacts of climate change on agricultural crop production using model simulations. Acad. Res. J. Agric. Sci. Res. 4 (5), 206-221.

Hanway, J.J., Heidel, H., 1952. Soil analysis methods as used in Iowa state college soil testing laboratory. Iowa Agric. 57, 1-31.

Hatfield, J.L., Prueger, J.H., 2011. Agroecology: implications for plant response to climate change. In: Yadav, S.S., Redden, R.J., Hatfield, J.L., Lotze-Campen, H., Hall, A.E. (Eds.), Crop Adaptation to Climate Change. Wiley-Blackwell, Oxford, UK, pp. 27-43. http://dx.doi.org/10.1002/9780470960929.ch3.

IPCC, 2014. The Physical Science Basis, Technical summary of Working Group I. Fourth Assessment Report Inter-Governmental Panel on Climate Change.

Jackson, R.D., Idso, S.B., Reginato, R.J., 1981. Canopy temperature as a crop water stress indicator. Water Resour. Res. 17, 1133-1138.

Jackson, M.L., 1973. Soil Chemical Analysis. Prentice Hall of India Private Limited, New 
Delhi.

Jones, H.G., 2013. Plants and Microclimate: A Quantitative Approach to Environmental Plant Physiology. Cambridge University Press.

Korte, L.L., Williams, J.H., Specht, J.E., Sorensen, R.C., 1983. Irrigation of soybean genotypes during reproductive ontogeny. I. Agronomic responses. Crop Sci. 23 (3), 521-527.

Kropff, M.J., Van Laar, H.H., Matthews, R.B., 1994. ORYZA1: an ecophysiological model for irrigated rice production. In: Kropff, M.J., van Laar, H.H., Matthews, R.B. (Eds.), SARP Research Proceedings. IRRI, Wageningen, Netherlands. (p. 110).

Lehmann, N., Finger, R., Klein, T., Calanca, P., Walter, A., 2013. Adapting crop management practices to climate change: modeling optimal solutions at the field scale. Agric. Syst. 117, 55-65.

Li, D., Liu, H., Qiao, Y., Wang, Y., Cai, Z., Dong, B., Shi, C., Liu, Y., Li, X., Liu, M., 2013. Effects of elevated $\mathrm{CO}_{2}$ on the growth, seed yield, and water use efficiency of soybean (Glycine max (L.) Merr.) under drought stress. Agric. Water Manage. 129, 105-112.

Lobell, D.B., Asseng, S., 2017. Comparing estimates of climate change impacts from process-based and statistical crop models. Environ. Res. Lett. 12 (1), 015001.

Ludwig, F., Biemans, H., Jacobs, C., Supit, I., van Diepen, C.A., Fawell, J., Capri, E., Steduto, P., 2011. Water Use of Oil Crops: Current Water Use and Future Outlooks. ILSI Europe aisbl.

Martre, P., Reynolds, M.P., Asseng, S., Ewert, F., Alderman, P.D., Cammarano, D., Basso, B., 2017. The International Heat Stress Genotype Experiment for modeling wheat response to heat: field experiments and AgMIP-Wheat multi-model simulations. Open Data J. Agric. Res. 3, 23-28.

Morell, F.J., Yang, H.S., Cassman, K.G., Van Wart, J., Elmore, R.W., Licht, M., Coulter, J.A., Ciampitti, I.A., Pittelkow, C.M., Brouder, S.M., Thomison, P., 2016. Can crop simulation models be used to predict local to regional maize yields and total production in the US corn belt? Field Crops Res. 192, 1-12.

Moshelion, M., Halperin, O., Wallach, R., Oren, R.A.M., Way, D.A., 2015. Role of aquaporins in determining transpiration and photosynthesis in water-stressed plants: crop water-use efficiency, growth and yield. Plant Cell Environ. 38 (9), 1785-1793.

Kumar, S.N., Aggarwal, P.K., Rani, D.S., Saxena, R., Chauhan, N., Jain, S., 2014. Vulnerability of wheat production to climate change in India. Clim. Res. 59 (3), 173-187.

Kumar, S.N., Aggarwal, P.K., Uttam, K., Surabhi, J., Rani, D.S., Chauhan, N., Saxena, R., 2016. Vulnerability of Indian mustard (Brassica juncea (L.) Czernj. Cosson) to climate variability and future adaptation strategies. Mitigation Adaptation Strategies Global Change 21 (3), 403-420.

Nielsen, D.C., Ma, L., Ahuja, L.R., Hoogenboom, G., 2002. Simulating soybean water stress effects with RZWQM and CROPGRO models. Agron. J. 94, 1234-1243.

Niu, S., Xing, X., Zhang, Z.H.E., Xia, J., Zhou, X., Song, B., Li, L., Wan, S., 2011. Water-use efficiency in response to climate change: from leaf to ecosystem in a temperate steppe. Global Change Biol. 17 (2), 1073-1082.

Olsen, S.R., Cole, C.V., Watanabe, F.S., Dean, L.A., 1954. Estimation of Available Phosphorus in Soil by Extraction with Sodium Bicarbonate. U.S. Department of Agriculture Report Circular No. 93.

Osakabe, Y., Osakabe, K., Shinozaki, K., Tran, L.S.P., 2014. Response of plants to water stress. Front. Plant Sci. 5.

Panse, V.G., Sukhatme, P.V., 1967. Statistical Methods for Agricultural Workers. Indian Council of Agricultural Research, New Delhi, India.

Pedersen, P., Lauer, J.G., 2004. Response of soybean yield components to management system and planting date. Agron. J. 96 (5), 1372-1381.

Penning de Vries, F.W.T., Jansen, D.M., ten Berge, H.F.M., Bakema, A.H., 1989. Simulation of Ecophysiological Processes in Several Annual Crops. Simulation Monograph. PUDOC, Wageningen, The Netherlands (p. 271).

Pessarakli, M. (Ed.), 2014. Handbook of Plant and Crop Physiology. CRC Press.

Pessarakli, M. (Ed.), 2016. Handbook of Plant and Crop Stress. CRC Press.

Prasanna, V., 2014. Impact of monsoon rainfall on the total foodgrain yield over India. J. Earth Syst. Sci. 123 (5), 1129-1145.
Revadekar, J.V., Preethi, B., 2012. Statistical analysis of the relationship between summer monsoon precipitation extremes and foodgrain yield over India. Int. J. Climatol. 32 (3), 419-429.

Richards, L.A., 1947. Pressure-membrane apparatus, construction and use. Agric. Eng. 28 (10), 451-454.

Robert, M., Thomas, A., Sekhar, M., Badiger, S., Ruiz, L., Raynal, H., Bergez, J.E., 2016. Adaptive and dynamic decision-making processes: a conceptual model of production systems on Indian farms. Agric. Syst. 157, 279-291.

Rosenzweig, C., Elliott, J., Deryng, D., Ruane, A.C., Müller, C., Arneth, A., Boote, K.J., Folberth, C., Glotter, M., Khabarov, N., Neumann, K., 2014. Assessing agricultural risks of climate change in the 21 st century in a global gridded crop model intercomparison. Proc. Natl. Acad. Sci. 111 (9), 3268-3273.

Sadras, V.O., Lake, L., Li, Y., Farquharson, E.A., Sutton, T., 2016. Phenotypic plasticity and its genetic regulation for yield, nitrogen fixation and $813 \mathrm{C}$ in chickpea crops under varying water regimes. J. Exp. Bot. 67 (14), 4339-4351.

Sentelhas, P.C., Battisti, R., Câmara, G.M.S., Farias, J.R.B., Hampf, A.C., Nendel, C., 2015 The soybean yield gap in Brazil-magnitude, causes and possible solutions for sustainable production. J. Agric. Sci. 153 (8), 1394-1411.

Sinclair, T.R., Purcell, L.C., King, C.A., Sneller, C.H., Chen, P., Vadez, V., 2007. Drought tolerance and yield increase of soybean resulting from improved symbiotic N2 fixation. Field Crops Res. 101 (1), 68-71.

Sinclair, T.R., Zwieniecki, M.A., Holbrook, N.M., 2008. Low leaf hydraulic conductance associated with drought tolerance in soybean. Physiol. Plant 132 (4), 446-451.

Sinclair, T.R., Messina, C.D., Beatty, A., Samples, M., 2010. Assessment across the United States of the benefits of altered soybean drought traits. Agron. J. 102 (2), 475-482.

Sinclair, T.R., Marrou, H., Soltani, A., Vadez, V., Chandolu, K.C., 2014. Soybean production potential in Africa. Global Food Security 3 (1), 31-40.

Sinclair, T.R., 2017. Soybean. Water-Conservation Traits to Increase Crop Yields in WaterDeficit Environments. Springer International Publishing, pp. 17-26.

Steduto, P., Hsiao, T.C., Fereres, E., Raes, D., 2012. Crop Yield Response to Water. FAO, Rome.

Subbiah, B.V., Asija, G.L., 1956. A rapid procedure for the estimation of available nitrogen in soil. Curr. Sci. 25, 259-260.

Tomeo, N.J., Rosenthal, D.M., 2017. Variable mesophyll conductance among soybean cultivars sets a tradeoff between photosynthesis and water-use-efficiency. Plant Physiol. 174 (1), 241-257.

van Ittersum, M.K., Cassman, K.G., Grassini, P., Wolf, J., Tittonell, P., Hochman, Z., 2013. Yield gap analysis with local to global relevance-a review. Field Crops Res. 143, 4-17.

van Laar, H.H., Goudriaan, J., van Keulen, H. (Eds)., 1997. SUCROS97. Simulation of Crop Growth for Potential and Water-limited Production Situations. Quantitative Approaches in Systems Analysis 14. Wageningen, The Netherlands. CT de Wit Graduate School of Production ecology and AB-DLO. p. 52.

Van Wart, J., Kersebaum, K.C., Peng, S., Milner, M., Cassman, K.G., 2013. Estimating crop yield potential at regional to national scales. Field Crops Res. 143, 34-43.

Walkley, A., Black, I.A., 1934. An examination of the Degtjareff method for determining soil organic matter and a proposed modification of the chromic acid titration method. Soil Sci. 37, 29-38.

Wiebbecke, C.E., Graham, M.A., Cianzio, S.R., Palmer, R.G., 2012. Day temperature influences the male-sterile locus in soybean. Crop Sci. 52 (4), 1503-1510.

Willmott, C., 1981. On the validation of models. Phys. Geogr. 2, 183-194.

Zhang, B., Feng, G., Kong, X., Lal, R., Ouyang, Y., Adeli, A., Jenkins, J.N., 2016. Simulating yield potential by irrigation and yield gap of rainfed soybean using APEX model in a humid region. Agric. Water Manage. 177, 440-453.

Zhang, D., Du, Q., Zhang, Z., Jiao, X., Song, X., Li, J., 2017. Vapour pressure deficit control in relation to water transport and water productivity in greenhouse tomato production during summer. Sci. Rep. 7, srep43461.

Zhou, S., Yu, B., Huang, Y., Wang, G., 2014. The effect of vapor pressure deficit on wate use efficiency at the subdaily time scale. Geophys. Res. Lett. 41 (14), 5005-5013. 